\title{
The Culinary and Food Science: Its' Integration via Kitchen Science Module (Cooking) to fascinate students towards Science, Technology, Engineering and Mathematics (STEM)
}

Rosmaliza Muhammad, Arni Abdul Gani, Norhidayah Abdullah, Shahariah Ibrahim, Mohd Shazali Md Sharif

To Link this Article: http://dx.doi.org/10.6007/IJARBSS/v10-i13/8550

DOI:10.6007/IJARBSS/v10-i13/8550

Received: 17 November 2020, Revised: 13 December 2020, Accepted: 31 December 2020

Published Online: 26 January 2021

In-Text Citation: (Muhammad et al., 2021)

To Cite this Article: Muhammad, R., Abdul Gani, A., Abdullah, N., Ibrahim, S., \& Sharif, M. S. M. (2021). The Culinary and Food Science: Its' Integration via Kitchen Science Module (Cooking) to fascinate students towards Science, Technology, Engineering and Mathematics (STEM). International Journal of Academic Research in Business and Social Sciences, 11(13), 310-320.

\section{Copyright: @ 2021 The Author(s)}

Published by Human Resource Management Academic Research Society (www.hrmars.com)

This article is published under the Creative Commons Attribution (CC BY 4.0) license. Anyone may reproduce, distribute, translate and create derivative works of this article (for both commercial and non-commercial purposes), subject to full attribution to the original publication and authors. The full terms of this license may be seen at: http://creativecommons.org/licences/by/4.0/legalcode

Special Issue: Beyond 2021 and COVID-19 - New Perspective in the Hospitality \& Tourism Industry, 2021, Pg. 310 - 320 


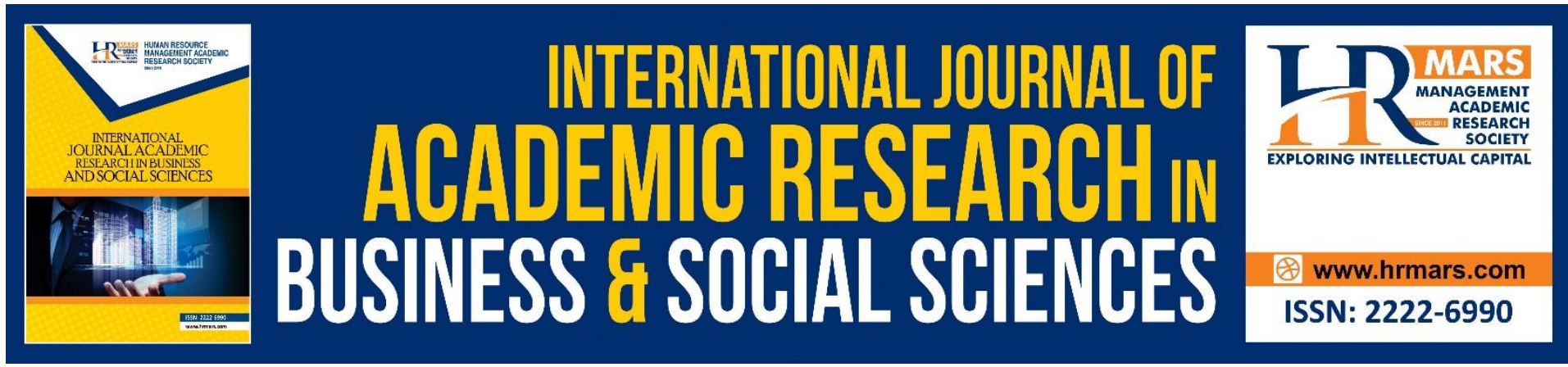

\title{
The Culinary and Food Science: Its' Integration via Kitchen Science Module (Cooking) to fascinate students towards Science, Technology, Engineering and Mathematics (STEM)
}

\author{
Rosmaliza Muhammad, Arni Abdul Gani, Norhidayah Abdullah, \\ Shahariah Ibrahim, Mohd Shazali Md Sharif
}

Faculty of Hotel and Tourism Management, Universiti Teknologi MARA, UiTM Puncak Alam Campus, 42300 Puncak Alam, Selangor, Malaysia

\begin{abstract}
Cooking is not only to satisfy hunger and to produce palatable food. Behind the arts of cooking, there is food related sciences involved that is often overlooked. Food science elements can be explored through fermentation of bread, coagulation of eggs during preparation of mayonnaise and Maillard reaction during the grilling process of steak. There are many other cooking processes that involve the elements of science. Thus, this study explores the integration of cooking and food science elements via Kitchen Science Module to fascinate Secondary School students towards the Science, Technology, Engineering and Mathematics (STEM) programme. A qualitative research through observation has been employed to achieve the objective of the study. Kitchen Science Module has been used as the major tool in examining the fascination level of students towards the STEM programme. A direct exposure of knowledge kitchen science plus direct involvement with the cooking processes would fascinate and motivate secondary school students to pursue their future study in related fields of science, technology, engineering, and mathematics specifically.
\end{abstract}

Keywords: Cooking, Kitchen Science, STEM, Food Science, Student

\section{Introduction}

The Malaysia Education Blueprint for 2013-2025 has included STEM Initiatives with the aims of preparing students with the skills to meet science and technology challenges to ensure Malaysia has enough qualified STEM graduates (MOE, 2013). This implies the importance of Science and Technology education which has always been a priority in Malaysia. STEM is an acronym for the study or professional practice in the broad areas of science, technology, engineering, and mathematics. This educational concern is driven by a large majority of secondary school students who fail to reach proficiency in math and science (Hernandez et al., 2014). Meanwhile, Brown (2012) reveals that STEM education research is a field of wide variety and unclear parameters. The lack of agreement on what STEM education is can be seen in the 
many different definitions of STEM education. Apart from that, the U.S. Department of Education. (2007) defines STEM education as an educational program for those primarily intended to provide support for or to strengthen STEM education at the elementary and secondary through postgraduate levels, including adult education.

Despite the government's commitment to align the STEM initiatives to the objectives of the New Economic Model, Economic Transformation Programme and the Government Transformation Plan launched in 2010, there are still great challenges in implementing Science Education in Malaysia (Shahali, Ismail \& Halim, 2017). One of the key issues that Malaysia has been battling is meeting the human capital demand that will be necessary in 2020 . The number of students who have chosen STEM fields has continued to decline in recent years (Halim \& Subahan, 2016). Currently, only $42 \%$ of middle school students in Malaysia choose to do science, including technical and vocational programs at high school. The percentage of middle secondary school students who meet the requirement to study science at upper secondary but choose not to do so increased to approximately 15\% (MOE, 2013). The current demand for STEM-capable workers surpasses the supply of applicants who have trained for those careers. The Ministry of Science, Technology, and Innovation (MOSTI) estimates that there will be a shortfall of 236,000 professionals in STEM-related fields (MOSTI, 2012). Given these shortfalls for a STEM-capable workforce, the nation's economic future depends on preparing more students to enter these fields.

Regarding international studies, for example, the trends in International Mathematics and Science Study (TIMSS) have shown disturbing trends among Malaysian students (Jayarajah, et al., 2014). The findings from the TIMSS suggest that the declining attitudes toward science education constitute an international crisis. In Malaysia, the TIMSS science score in 2007 had decreased radically to 471 points, 40 points lower than the score of TIMSS 2003. Amongst 59 countries taking part in TIMSS 2007, the cumulative score of science achievement for Malaysia Form 2 (grade 8) students showed the most significant decline compared to other countries. TIMSS 2011 revealed the same trend with science decreased to 426 points, 45 points lower than the score in 2007 (IEA, 2012).

The Higher Education Planning Committee aims for $60 \%$ science stream and $40 \%$ art stream students at upper secondary school. Nevertheless, the results show that the 60:40 policy is yet to be achieved. This issue is clear when only $20 \%$ of the 472,541 students who sat for the Malaysian Certificate of Education or commonly known as SPM (a national examination taken by all grade 11 students in Malaysia in 2012 were science-stream students. The decrease in the number of students in the science stream is alarming. At tertiary education, statistics indicated that the inclination of students' interest is toward the social sciences, business, and law courses (MOE, 2013).

Nevertheless, the new STEM approaches in Malaysian science education is aiming at making science more appealing to students and indirectly inviting more students to pursue their studies in science related areas to realize Malaysia's goal of becoming an industrialized country (Saat, 2012). The increasing flow in the STEM education pipeline has become a better way to motivate young minds to further their interest in science and mathematics (Rhoads, Walden \& Winter, 2004) by using meaningful learning context and relate to student real life as 
mentioned in the six core STEM integration (Johnson, Peters-Burton, \& Moore, 2016). In line with its mission, the Faculty of Hotel and Tourism Management, Universiti Teknologi MARA Selangor, Malaysia (UiTM) has developed the Kitchen Science Module to attract and motivate students to pursue their studies in science related fields. The module has been published in 2018 and integrated the daily routine practices in food preparation. The Kitchen Science Module has been used in STEM@UiTM activities at pilot schools under the Department of Education Selangor. This paper reports the initial finding of the feasibility of using the Kitchen Science Modul as a medium to stimulate students' interest towards STEM education.

\section{Literature Review Introduction to Stem Education}

STEM is designated curriculum where four specific disciplines which include science, technology, engineering, and mathematics are integrated in educating students for an interdisciplinary and cohesive learning paradigm based on real-world applications. STEM is an educational concept where science is taught integrative with technology, mathematics, language, and other subjects with the aim to create meaningful learning, enrich students' learning experiences, enhance their understanding, and shift their attitudes and soft competencies (Mashita, Ramli \& Karyanto, 2017).

The shortage of science, technology, engineering, and mathematics (STEM) graduates and the small numbers of people who plan to pursue a STEM major or career, are some of the major issues that necessitates STEM education as a global priority. In Malaysia, the STEM implementation has been as early as 1970 when the first National Science and Technology Enrolment Policy of 60:40 being introduced, which guaranteed that 60 percent of students would be enrolled in science with the remaining 40 percent in arts. While in 1991, Vision 2020 was implemented with one of the goals is to establish a scientific and innovative society. Consequently, 69 science secondary schools and 51 Mara Junior Science Colleges has been established to achieve the goals. The high aspiration of Malaysia in achieving this goal can be clearly seen when Ministry of Education initiated the Malaysia Education Blueprint in 2011 with STEM as one of the priorities identified in the blueprint. In addition to it, is the incorporation of computational thinking, aimed to groom the young digital citizens and future innovators in a rapidly evolving world. It exhibits that Malaysia is moving closer to establish a scientific and innovative society (Kementerian Pelajaran Malaysia, 2013).

The decisiveness of the plan has since, revealed that students who have an increased interest in science, mathematics, and engineering in the early years of their education are more likely to pursue that interest resulting in a STEM-related career (America After 3PM Special Report, 2015). However, STEM subjects have been labelled as too challenging, boring, and/or uninteresting by many students which restrict their participation in STEM subjects and activities. Thus, an alternative approach needs to be undertaken to resolve these issues.

\section{Approach to Integrating Stem in Learning}

STEM is more than just an acronym for science, technology, engineering, and mathematics. It is a skill or a philosophy in a way where it involves an approach and a way of thinking for educators in assisting students to gain knowledge beyond subjects taught in class in an enjoyable and interesting learning ambient, hence an enhanced quality of teaching. 
Several methods or approaches can be undertaken to enhance the quality of education. A student-centered learning $(\mathrm{SCL})$ approach is a system whereby instruction given to the student at its heart with creative visual aids as well as other teaching aids provided assist the students in understanding the STEM concept (Sri Mulyani \& Kawedhar, 2017). In addition, STEM also occupy students with the skills to gather and study information (investigative skills of science), evaluate and make sense of information (analytical skills of mathematics) and determine how the information gained help them to solve a problem (inventive skills of engineering) by using the available technology around them in the informal learning technique. The informal learning environments implemented was claimed as the catalyst that motivate and increase the students' interest towards STEM (Mohr-Schroeder et al., 2014) and inspiring the students to pursue a STEM career (Kitchen, Sonnert \& Sadler, 2018). Through informal learning, the interesting learning experiences help the students to learn more effectively. It is in line with Brown, Concannon, Marx, Donaldson and Black (2016) where they found that student interest played a key role in intention to persist in STEM education.

In general, formal learning is applied in a solitary form of educational system (Martin, 2004), whereas, informal learning giving broader opportunity to connect and intermingle with peers (Barker, Larson \& Krehbiel, 2014; Denson, Hailey, Stallworth \& Householder, 2015). By conducting the informal learning approach, students being exposed to the 'real world problem-solving approach.' This learning approach can motivate students to learn and improve their interest, achievement, and persistence which develops positive STEM perception and giving students the opportunities to participate in authentic STEM learning experiences. For these reasons, an informal learning environment needs to be provided for meaningful exposure to a STEM community in which they are free to participate, practice, and belong (O'Connell, Keys \& Storksdieck, 2017).

Thus, this module is outlined with the aims to provide an informal STEM learning opportunity to the secondary school students with a focus on the school with minimum numbers of students embarked on the science stream classes. The researchers are optimistic and confident, every student has the potential provided with the opportunities, to gain an authentic learning experiences by exploring STEM via the "Kitchen Science" Module. It is hoped that the informal STEM learning provided in this module, will develop an interesting and memorable experience on student participants, and prepare themselves for their life and give positive perception towards STEM learning.

\section{Methodology}

The common paradigm for module design and delivery in education is one where delivery and content is driven by the lecturer or module leader (Biggs \& Tang, 2011). The module must be developed with the intention to provide learning outcomes, clear means of delivery and the assessment to be carried out. The Kitchen Science Module was thus created with the intention to fascinate students' interest in science, technology, engineering and mathematic through hands-on activities, doing and preparing some of the common cooking activities in the kitchen. It was developed with reference to Malaysian Secondary Syllabus from the Ministry of Education, Malaysia. 
Both topics under this module were developed to meet the objectives of the study. The first topic is Science of Yeast. This was developed in accordance to one of the topics in Science syllabus for Form 5; Microorganism and its effects on living things. The second topic is Eggs and its functions. This topic was designed based on the topic Food Technology and Production in Science syllabus for Form 5 as well. The module design was then presented to a group of academicians in Universiti Teknologi MARA Shah Alam. A purposive sampling was used to select the expert respondents from various STEM background, where they were presented with the module and were asked to give their comments and feedbacks. Amendments were then made on the module to enhance its application for the students.

The module was then administered to 2 groups of secondary school children in Selangor as pilot study for this research. 5 lecturers and 10 undergraduate students from the Faculty of Hotel and Tourism Management, Puncak Alam campus were appointed as facilitators and assistants that took part in administering these modules. The 2 schools selected were the pilot schools for STEM@UiTM education under the Selangor Education Department. A total of 150 students from both schools had participated during the sessions. An observation method was found most useful and appropriate to be conducted at this early stage of the module's sessions. This method had provided ways to check for nonverbal expression of feelings from the students, able to determine who interacts with whom, grasp how students communicate with each other and the facilitators and assistants and checked for how much time was spent on various activities. The facilitators and the assistants were supplied with a reference list of items they can observe during the sessions; time taken to finish the module, the completed observation forms and the expression feelings by the students both verbal and nonverbal. 


\section{Results and Analyses}

The table below depicts the description for Kitchen Science Module for STEM education. The module consists of 2 topics with 4 activities to be carried out during session in schools.

Table 1: Description of Kitchen Science Module

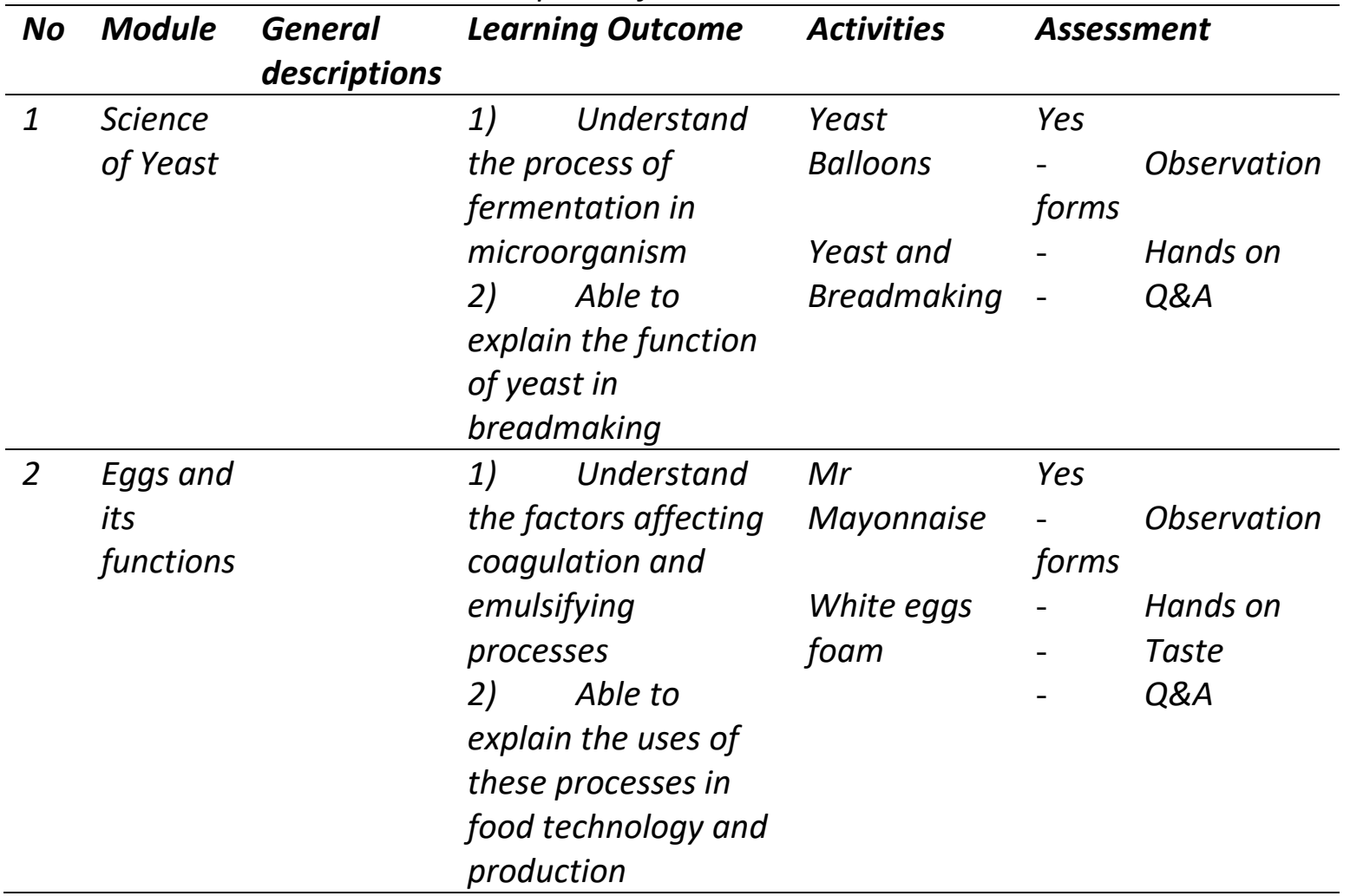

Both topics use an informal approach for enlightening the students about the processes involved as they take part in the activities. Activities in the module were chosen because they are easy to administer, allow for considerable time to observe reactions and to provide elements of fun and enjoyment to fascinate students' interest. Observation forms are provided as part of the assessment to test students' understanding and stimulate their curiosity over the outcome of each activity. Hands-on activities are part of the assessment to engage them and allow for personal experience with the module.

\section{Observation Results}

\section{Time to Finish the Module}

Each of the activities was carried out within 1 to 1.5 hours involving 4 to 6 groups of school children at a time. They were given a brief description on the administration for the experiments and activities. The facilitator and their assistants were then demonstrated each of the activities followed by hands-on sessions by the students. During the sessions, they were given opportunity to do the activity from beginning and to observe the results. They were given observation forms to fill in to record what they saw and to draw into conclusions. A question and answer ( $Q \& A$ ) session followed at the end of each activity. 


\section{Completed Observation Forms}

The observation forms act as a means to record and to assess the students' understanding on the concept of science in the kitchen. The questions asked in the form were related to the experiments and activities carried out. The discussions on the activities were carried out during the $Q \& A$ sessions.

\section{Participation and Expressions by students}

As mentioned earlier, the facilitators and their assistants were reminded to observe the students' expressions verbally and non-verbally during the module. During the sessions in both schools, all targeted group of students participated and had the opportunity to experience hands-on practice on the activities. Below is the feedback generated from the facilitators and the assistants on their observations of the students.

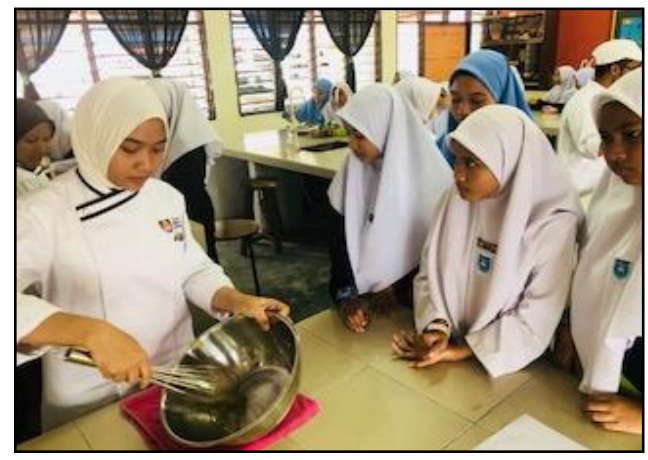

Figure 1: A demonstration by the assistant

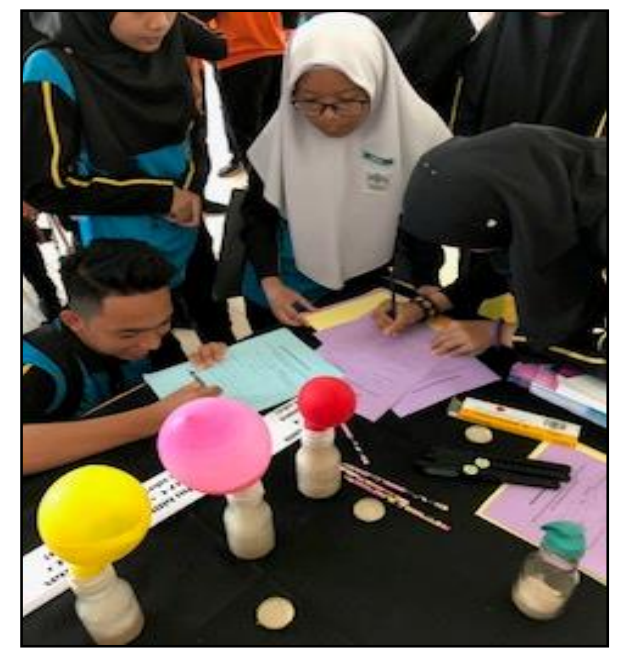

Figure 3: Students were asked to fill up the observation activity form

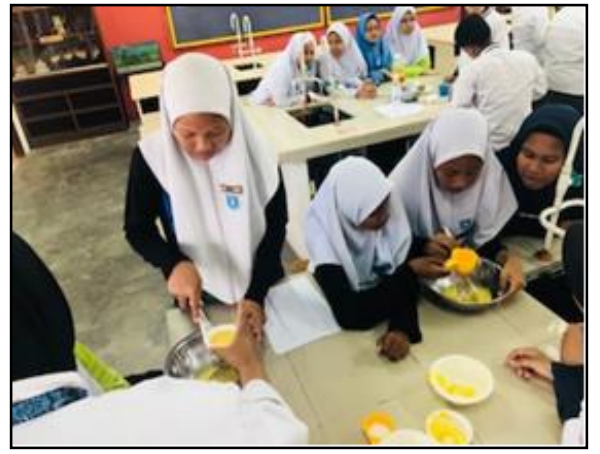

Figure 2: Students take part in hands on

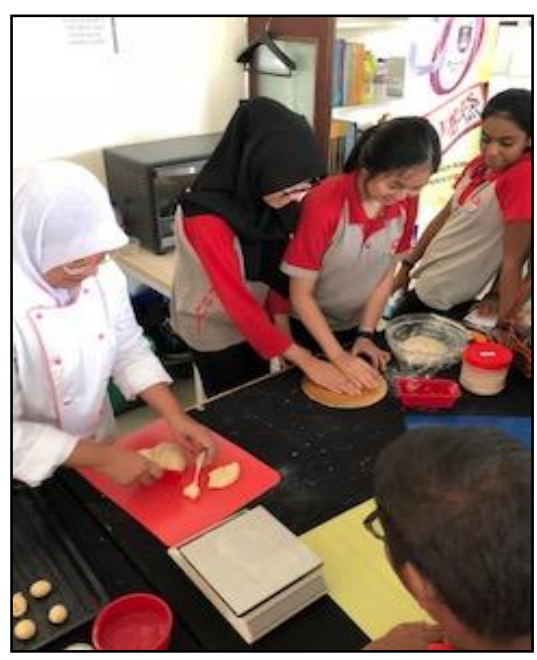

Figure 4: Students take part in kneading activity 
Table 2: Recorded feedback

\begin{tabular}{|c|c|}
\hline No & Feedback from facilitators/assistants \\
\hline 1 & "They were happy and very curious to learn..." (Facilitator 1, Facilitator 4) \\
\hline 2 & “...students said the exercise is fun.." (Facilitator 3, Assistant 3, Assistant 7) \\
\hline 3 & "...each and every one of them are eager to try" (Assistant 2) \\
\hline 4 & $\begin{array}{l}\text { "when asked if they have questions, I can see quite a number of hand.." (Facilitator } \\
\text { 4) }\end{array}$ \\
\hline 5 & $\begin{array}{l}\text { “...the student said mayonnaise is tasteful..not like what bought at shop.." (Assistant } \\
\text { 1) }\end{array}$ \\
\hline 6 & $\begin{array}{l}\text { "...one of the student said this is good because they can be out of class...doing } \\
\text { something else.." (Facilitator } 1 \text {, Facilitator } 2 \text { ) }\end{array}$ \\
\hline 7 & "...they said the experiments so related to what they do at home.." (Assistant 5) \\
\hline 8 & $\begin{array}{l}\text { "they want to try knead the bread...and keep asking if they are doing it right..which } \\
\text { is very happy to me" (Facilitator } 5 \text { ) }\end{array}$ \\
\hline 9 & $\begin{array}{l}\text { "they are having fun, you can tell from their happy face and eagerness to try" } \\
\text { (Facilitator 3, Facilitator 5, Assistant 1) }\end{array}$ \\
\hline 10 & $\begin{array}{l}\text { "..the students really like it when I say you can taste the mayonnaise ..." (Assistant } \\
\text { 9) }\end{array}$ \\
\hline
\end{tabular}

The feedback gained from this pilot study has provided some interesting initial findings on the effectiveness of integrating cooking and food science to help students in secondary schools to spark their interest in science. Students were recorded to feel happy and fun, induce interest to learn about cooking and science, feel happy and good about the opportunity to learn outside of the classroom. They are eager to learn and take part in the activities which affirm their fascination towards the module. Furthermore, the hands-on and taste assessment are a bonus to be added to the module as studies have shown that students learn best when learning is active. Scientists believe that when students use all their senses it helps the brain create pathways that make it easier and quicker to retain information (Cox, 2018).

Food Science can be used as a tool in integrated curricula to enhance STEM education, coupled with the scientific diversity of food make it a perfect fit to incorporate content from all STEM disciplines. Furthermore, exposing students to the complexity of the food chain, food safety, and food science at a young age sets them up to be informed and educated consumers throughout their lives (Edwards, 2018). This supports one of the initial agenda in formulating the module, which is to supplement long life education to the youngsters

\section{Conclusion}

Understanding science, technology, engineering, and mathematics is slightly challenging especially for the non-science students. However, by incorporating correct and suitable approaches, the learning of STEM education can be improved. Kitchen Science Module was specially designed with the aims to fascinate students' interest and enhance their understanding towards science, technology, engineering, and mathematical subjects. The hands-on activities provided in the module were able to create enjoyable learning experiences, add a holistic approach in learning by doing, encourage interactions between teachers and learners and setting out new examples to learn science at schools. It can be 
concluded from this pilot study, that the Kitchen Science Module has the potential to facilitate the learning of STEM for students. It is therefore suggested that this module can be used as an effective learning pedagogy to arouse secondary school students' interest towards STEM.

\section{Acknowledgment}

Special thanks to STEM@UiTM, under Centre of Strategic Planning and Innovation CSPI, Universiti Teknologi MARA and Department of Education Selangor (JOS) and the students at both schools for participating in the Kitchen Science Module

\section{Corresponding Author}

Rosmaliza Muhammad. Faculty of Hotel and Tourism Management, Universiti Teknologi MARA, UiTM Puncak Alam, 42300 Puncak Alam, Selangor, Malaysia.

Email: rosmaliza35@salam.uitm.edu.my

\section{References}

America After 3PM Special Report (2015). Full STEM ahead: afterschool programs step up as key partners in STEM education. America, After-School Alliance.

Barker, B. S., Larson, K., \& Krehbiel, M. (2014). Bridging formal and informal learning environments. Journal of Extension, 52(5), 1-5.

Biggs, J., \& Tang, C. (2011). Teaching for quality learning at university. United Kingdom, McGraw Hill Education.

Brown, J., Brown R., \& Merrill, C. (2012). Science and technology educators' enacted curriculum: areas of possible collaboration for an integrative STEM approach in public schools. Technology Teacher, 71(4), 30- 34.

Brown, P. L., Concannon, J. P., Marx, D., Donaldson, C. W., \& Black, A. (2016). An examination of middle school students' stem self-efficacy with relation to interest and perceptions of STEM. Journal of STEM Education: Innovations and Research, 17(3), 22-27.

Citra, M., Ramli, M., \& Karyanto, P. (2017). Practices of inquiry-based science education: case study of Thailand's junior high school. Pertanika Journal of Social Science and Humanities, 25(S), 51-72.

Cox, J. (2018). Improve learning with hands-on classroom games, activities. Malaysia, KPM Publisher.

Denson, C. D., Hailey, C., Stallworth, C. A., \& Householder, D. L. (2015). Benefits of informal learning environments: a focused examination of STEM-based program environments. Journal of STEM Education: Innovations and Research, 16(1), 11 - 15.

Edwards, C. (2018). Using food science to enhance STEM education. Manhattan, Purdue University Press.

Halim, L., \& Subahan, A. (2016). Science education research and practice in Malaysia, Science Education Research and Practice in Asia. Singapore, Springer.

IEA. (2012). TIMSS 2011 international science report: findings from IEA's trends in international mathematics and science study at the fourth and eighth grade. Boston, MA Publisher.

Hernandez, P. R., Bodin, R., Elliott, J. W., Ibrahim, B., Rambo-Hernandez, K. E., \& de Miranda, M. A. (2014). Connecting the STEM dots: Measuring the effect of an integrated engineering design intervention. International Journal of Technology and Design Education. Int J Technol Des Educ 24, 107-120. 
Jayarajah, K., Saat, M. R., \& Abdul Rauf, R. A. (2014). A review of science, technology, engineering \& mathematics (STEM) education research from 1999-2013: A Malaysian perspective. Eurasia Journal of Mathematics, Science \& Technology Education, 10(3), $155-163$.

Johnson, E. E., Peters-Burton, A. \& Moore, T. J. (2010). STEM road map: A framework for integrated STEM education. New York, Routledge Taylor \& Francis Group.

Kementerian Pelajaran Malaysia. (2013). STEM education: policies and prospects toward achieving international standard and meeting national development needs. Kuala Lumpur, KPM Publisher.

Kitchen, J. A., Sonnert, G., \& Sadler, P. M. (2018). The impact of college-and university-run high school summer programs on students' end of high school stem career aspirations. Science Education, 102(3), 529- 547.

Martin, L. M. W. (2004). An emerging research framework for studying informal learning and schools. Science Education, 88(1), S71-S82.

MOE. (2013). Pelan pembangunan pendidikan Malaysia 2013-2025 (Pendidikan Prasekolah hingga Menengah). Putrajaya, KKM publisher.

MOSTI. (2012). Science and technology human capital roadmap: towards 2020. Putrajaya, Malaysian Science and Technology Information Centre.

Shahali, M. E., Ismail, I., \& Halim, L. (2017). STEM Education in Malaysia: policy, trajectories, and initiatives. Science and Technology Trends, 122-133.

Mohr-Schroeder, M. J., Jackson, C., Miller, M., Walcott, B., Little, D. L., Speler, L., Schooler, W., \& Schroeder, D. C. (2014). Developing middle school students' interests in stem via summer learning experiences: see blue STEM camp. School Science and Mathematics, 114(6), 291-301.

Rhoads, T. R., Walden, S. E., \& Winter, B. A. (2004). Sooner element engineering and science (SEES) a model for after school science clubs based on university and K-5 Partnership. Journal of STEM Education, 5(3), 47-52.

O'Connell, K. B., Keys, B., \& Storksdieck, M. (2017). Taking stock of oregon STEM hubs: accomplishments and challenges. Corvallis: Oregon State University.

Mulyani, S., \& Kawedhar, M. C. S. (2017). Creative visual aids effectively supporting the student-centred learning (SCL) approach on science learning. Pertanika Journal of Social and Humanities, 25(S), 187-198.

Saat, R. M. (2012). Practices in mathematics \& science education: A reflection in Akmar, S. N. (Ed.), what we learned from science education reform: The Malaysian experience. Selangor, Pearson.

U.S. Department of Education, (2007). Report of the Academic Competitiveness Council. ED Pubs, Education Publications Center, Washington. 